\title{
How Do Local Governments Cope with COVID-19? Comparative Experiences in Three Southeast Asian Cities
}

\author{
Ridho Al-Hamdi ${ }^{1}$ Halimah Abdul Manaf, ${ }^{2}$ Non Naprathansuk, ${ }^{3}$ and Alim Bubu Swarga ${ }^{4}$ \\ 1,4Department of Government Affairs and Administration, Universitas Muhammadiyah Yogyakarta, Yogyakarta, Indonesia \\ ${ }^{2}$ School of Government, Universiti Utara Malaysia, Sintok, Malaysia \\ ${ }^{3}$ School of Administrative Studies, Maejo University, Chiang Mai, Thailand \\ ${ }^{1}$ Corresponding Author: ridhoalhamdi@umy.ac.id
}

Article Info

Article History;

Received:

2021-11-26

Revised:

2022-01-31

Accepted:

2022-02-04

\begin{abstract}
This paper is aimed to investigate strategies of Southeast Asian local governments in addressing the COVID-19 situation by applying the framework of good governance principles and, in turn, to figure out the determinant factor of the successful strategy in each country. It is qualitative research by applying multiple cases of three cities in Southeast Asian countries, i.e., Indonesia, Malaysia, and Thailand. For data gathering, it takes relevant sources of News channels, whether in English or local languages of those countries. The finding demonstrates that Indonesia, Malaysia, and Thailand can adopt all principles of good governance in addressing the COVID-19 pandemic situation. Nevertheless, each country has its determinant factor of the successful strategy in handling a such situation. Indonesia is more excellent in the implementation of transparency, Malaysia has a well performance in the operation of participation, while Thailand is more successful in the application of accountability. These depict that each state has a typical strategy in coping with this global pandemic situation.
\end{abstract}

Keyword: Local government; COVID-19; Good governance; Southeast Asia.

DOI: https://doi.org/10.18196/jgpp.v9i1.13242

\section{INTRODUCTION}

The global pandemic, Novel Coronavirus Disease (COVID-19), has become a critical concern for any international communities after the first case was reported by the World Health Organization (WHO) Office in Wuhan City, China (World Health Organization, 2020). Since the early of 2020, this disease continues to grow and spread swiftly to various countries worldwide, such as South Korea, Japan, Thailand, the United States, and France, which earlier reported the first case of COVID-19 outside China. Thus, the emergence of COVID-19 as a new coronavirus which can infect humans has caused many countries to be overwhelmed in preventing this virus transmission. Even countries which are known for having an advanced health system are also made desperate to cope with this virus. For instance, in Europe, Italy, which is famous for having an excellent health system, was reported as the number one country with the most COVID-19 victims (BBC, 2020). Similarly, the United States experienced the same problem with Italy in addressing this virus (Aljazeera, 2020).

In Southeast Asia, COVID-19 has also stretched out to all countries inside the region. According to a WHO report on January 13, 2020, Thailand's Ministry of Health reported the first 
case of COVID-19 transmission (World Health Organization, 2020). With that, Thailand is confirmed as the first country in Southeast Asia which infected by this new coronavirus. Shortly after Thailand reported its first case, Singapore, Vietnam, Malaysia, Cambodia, and the Philippines, were announced their first COVID-19 case at the end of January 2020. Meanwhile, other countries in Southeast Asia; Lao People's Democratic Republic, Indonesia, Myanmar, Brunei Darussalam, and Timor-Leste, were conclusively reported their first COVID-19 case in March 2020. From this point, none of the countries in Southeast Asia is free from the COVID-19 infection, and the number of confirmed cases keep increasing day by day. As released by WHO that from 22 June 2020 to 16 May 2021, positive confirmed cases of COVID-19 in Southeast Asia have increased dramatically from 130,713 to 3,679,592 and, in turn, it caused the death toll from 3,848 to 72,915 by the highest positive case and the death toll in Indonesians.

The widespread of COVID-19 in various countries rapidly led the WHO to enforce this coronavirus as a pandemic on March 11, 2020 (World Health Organization, 2020). This situation obviously needs all countries to prepare the best strategy in addressing this pandemic. A variety of different policies are taken by Southeast Asian governments. Indonesia, Malaysia, and Thailand, which will be the focus of case studies in this study, take a different approach in coping with the COVID-19. On March 18, 2020, the Malaysian Government has decided to implement a lockdown policy "Movement Control Order (MCO)" to restrict community movements in preventing the spread of COVID-19, which was increasingly extensive (Wong, 2020). In Thailand, the Thai Government prefers to implement a partial lockdown policy since March 26, 2020. The partial lockdown regulation is a follow-up to Thailand's emergency status after experiencing an increase in COVID-19 cases (Bloomberg, 2020). This partial lockdown policy aims to restrict the community's movement, including the closure of public spots, tourism, and entertainment. In addition to that, the Thai Government has imposed a curfew with police custody which aims to reduce community activities at night. Thus, Thailand also closed the border with surrounding countries and tightened inspection protocols at airports for tourists who want to enter Thailand.

In contrast with Malaysia and Thailand, on March 31, 2020, the Indonesian Government prefers to apply large-scale social restrictions (PSBB) policy rather than lockdown policy as an option to deal with the COVID-19 virus. In its implementation, this policy aims to limit people activities in public places and set the distance between them. This policy was taken as a step to reduce the negative impact of COVID-19 on public health and the Indonesian economy (CNBC, 2020). Although various policies and strategies have been formulated by the Governments of Malaysia, Thailand, and Indonesia; however, the role of local governments in handling COVID-19 is also vital to discuss in this research. For this reason, it is exciting and essential to look further on the strategy of local governments in Malaysia, Thailand, and Indonesia in coping with the emergence of the COVID-19 virus. By choosing one city in Indonesia, Malaysia, and Thailand as a model in addressing the COVID-19, this study is aimed to explain the strategy of local governments in Indonesia, Malaysia, and Thailand to deal with the COVID-19. This study's central question is: How do local governments in Indonesia, Malaysia, and Thailand deal with COVID-19?

Some papers studied this topic. Satispi et al. (2021) argue that the South Tangerang City Government in Indonesian applies some socialization types to inform the government policy on Covid-19 pandemic, whether through online or printed media. It is effective for them. Similarly, Angel \& Mudrazija (2020) put forward that the effort of Austin's local government in Texas, America, in making a strong partnership with non-profits and for-profit businesses are a successful instance in facilitating older adults' life among this pandemic situation. Nemec \& Špaček (2020) also hypothesize that this pandemic has a crucial impact on the municipal fiscal imbalance in Szechia and Slovakia, and, in turn, the municipal financial resources are not commensurate with their responsibilities. In the same vein, Green \& Loualiche (2020) postulate that local governments in America cope with larges losses in revenues and increased expenditures due to this pandemic, and, in turn, this crisis can lay off hundred thousand employees. Thus, Afonso (2021) argues that counties and municipalities in North Carolina, America, prepares for these reductions in revenue by avoiding in the creation of new staff positions, instituting hiring freezes, appropriating fund balance at higher levels, reducing capital expenditures, and closing facilities. 


\section{Introducing Good Governance Indicators}

In the contemporary world, there has been a common consensus that good governance is essential for human resource development in any society or state. The concept of good governance was developed primarily by multilateral development institutions. The World Bank (1992) described good governance, synonymous with sound development management, as the manner in which power is exercised in the management of a country's economic and social resources for development. Good governance is central to create and sustain an environment which fosters equitable and robust development, and it is an essential component for sound economic policies. Therefore, the government plays a vital role in the provision of public goods and establishes the rules which make markets work efficiently and corrects for market failure.

Likewise, the United Nations Development Programme (1997) defined good governance as the exercise of economic, political and administrative authority to manage a country's affairs at all levels. Economic governance encompasses the decision-making process which affects the country's economic activities and its relationships with other economies. Political governance is the process of decision-making to formulate policy. Administrative governance is the system of policy implementation. As a result, the UNDP assumed that democratic governance should embrace mechanisms, processes and institutions which determine how power is exercised, how decisions are made on public issues, and how citizens articulate their interests, exercise their legal rights, meet their obligations, and mediate their differences.

Meanwhile, the IMF (2014) argued that good governance is a broad concept covering all aspects of the way a country is governed, embracing its economic policies and regulatory framework as well as adherence to the rule of law. It emphasised promoting good governance when providing policy advice, financial supports, and technical assistance to its member countries. In addition, it also has strong measures in place to ensure integrity, impartiality, and honesty in the discharge of its own professional obligations. However, the IMF (1997) expressed concerns related to macroeconomic stability, external viability, and orderly economic growth in member countries. Its involvement in governance should be restricted to economic aspects of governance.

Moreover, a research project organised by Tim Indonesia Governance Index (2014), defined good governance as the process of formulation and implementation of rules, regulations, and development priorities through interaction among executive and legislative branches and bureaucracy with participation from civil society and economic society. Hence, the United Nations Development Programme (1997) and Tim Indonesia Governance Index (2014) agreed that there are four key actors in the governance arena: executive wing, legislative wing, civil society, and economic society. These institutions should contribute to sustainable human development. Therefore, this study defines good governance as the manner and bridge for people's basic needs, social justice, stability and freedom by utilising local resources and revenues as well as applying the six principles above. This can be achieved through the legal and elected government and other legal democratic institutions such as bureaucracy and the legislative body which are incorporated with other non-government actors: civil society and economic society.

In this context, the strategies of local governments in Southeast Asia in coping with COVID-19 will be assessed by good governance indicators. This study applies six indicators developed by World Bank (1994), United Nations Development Programme (1997), and Tim Indonesia Governance Index (2014) which the most suitable in terms of this case:

1. Participation. It can be seen in the engagement of stakeholders in the decision-making processes and its implementation related with COVID-19 issues.

2. Fairness. It can be seen from the condition where policies and programs related with COVID-19 are applied fairly to anybody without any discrimination.

3. Accountability. It is the condition where officials, institutions, and organizations in each area are held responsible for their action and inaction related with COVID-19.

4. Transparency. It can be proven with the condition where decisions made by officials in the government institutions, civil institutions, and private organizations in each city are open to the public to observe, scrutinize and evaluate and where public information is available and accessible. 
5. Efficiency. It can be assessed by the condition where policies and programs implemented have optimally utilized the resources.

6. Effectiveness. It is the output of the programs that has been achieved in line with the intended purpose.

\section{RESEARCH METHOD}

This article utilises qualitative method (Denzin \& Lincoln, 2011) by applying a multiple case study approach because it is an intensive investigation that describes multiple cases through indepth data collection by gathering various sources (Creswell, 2013; Flyvbjerg, 2011). Selecting cities in Indonesia, Malaysia, and Thailand are representatives because they have a high case of Covid-19 in the Southeast Asia region. This study applies good governance indicators in the assessment ofthree local governments' strategies in dealing with this pandemic. Thus, it can be known the difference strategy in each city, and, in turn, indicates that each city has different way to address this pandemic. To gather data, it employs news data taken from credible online news spreading on the internet before, during, and after the field research. After data collected, as theorized by Creswell (2013), the last step is analysis into four steps: reducing data, displaying data, drawing and verification, and conclusion.

\section{RESULT AND DICUSSION}

\section{Strategies of Indonesia's Tegal City in coping with Covid-19}

In the Tegal City case, the participation is reflected in at least two policies: the existence of a strict prohibition against mudik (going back home) and the provision of rapid tests and spraying of mass disinfectants. By responding to the Ramadhan Month's arrival amid the COVID-19 pandemic in Indonesia, the central government is calling for a ban on going home as regulated in the Transportation Minister's regulation No. 25 of 2020 concerning the Transportation Control during the IdhulFitri $1441 \mathrm{H}$ to prevent the broader spread of COVID-19. This has led to many deceptions, such as hiding in trucks, using agents, and other deceptions. Therefore, the Municipal Government of Tegal implemented large-scale social restrictions (PSBB) to hinder travellers from outside the area (Kompas TV, 2020). In addition, they cancelled the operational budget for pemudik, which is a very common event that occurs every year. Besides, the city of Tegal office coordinated with the police sub-districts, the RT/RW to report if vehicles from outside Tegal are expected. With this, subsequent communities in Tegal City will begin monitoring people who travel outside of the city. Furthermore, residents of Tegal City strongly regard the mandatory testing and spraying of mass disinfectants, the application of the PSBB, and the prohibition on going home (Kompas, 2020).

In terms of fairness, the local lockdown in Tegal City is implemented on different scales and applied to all communities. The access to the entrance and exit of Tegal has been blocked by a movable concrete barrier (MCB) (NewsDetik, 2020). Thus, for the communities wanting to enter Tegal City, they must be comprehensively checked for their health. With that, the Tegal City Government held a rapid mass test for their people. However, the number of COVID-19 infected cases is high, and infection rates are hindered by limited testing capabilities. Despite the phenomenon above, social safety net assistance is still provided by the municipal government in Tegal, Central Java. However, tens of thousands of residents affected by this pandemic and did not receive food packages. Only 16,356 families received support from the city government for three days before implementing the Large-Scale Social Restrictions (PSBB) (Gatra, 2020).

In the accountability, the Tegal Municipal Government implemented this principle well in handling the COVID-19. To prevent the widespread of the COVID-19 in Indonesia, the Mayor of Tegal, Dedy Yon Supriyono, implemented a local lockdown policy after the first COVID-19 was detected in Tegal City. This then applied to the Tegal City category for the COVID-19 incident in Indonesia. In addition, the Municipal Government of Tegal only opens one main road (proklamasi), which will facilitate access to logistics and medical equipment that will be distributed in Tegal City. Residents who work outside of Tegal must meet several local government requirements and are then subjected to the COVID-19 task force (Detik, 2020). In 
addition, emergency hospitals and public buildings were also converted into quarantine places and to serve patients infected with COVID-19 (Republika, 2020). Even so, the Municipal Government of Tegal fully understands and recognizes that this policy is controversial and will cause pros and cons in the central government and the community and, in particular, those with low incomes (Republika, 2020).

In the transparency, Tegal City attempts to strengthen its policy and improve its transparency. The city government passed a policy mandating that at least 60 percent of the 61,285 heads of families in the city would receive social assistance. In Tegal City, the House of Representatives will also discuss the aid to people and reallocate the budget for coping with the COVID-19 (jatengprov.go.id, 2020). Moreover, these refocusing and budget reallocation are under a social safety net regulation of Ministry of Home Affairs (Merdeka, 2020). Likewise, social assistance for Tegal City is divided into support from the Municipality of Tegal, Central Java Provincial Government, and the Central Government that can be seen on Table 1.

Table. 1 COVID-19 Social Assistance in Tegal City

\begin{tabular}{|c|c|c|c|}
\hline Program & $\begin{array}{c}\text { Central Government } \\
\text { (Ministry of Social Affairs) }\end{array}$ & $\begin{array}{l}\text { Central Java } \\
\text { Government }\end{array}$ & $\begin{array}{l}\text { Tegal City } \\
\text { Government }\end{array}$ \\
\hline $\begin{array}{l}\text { Indonesian Conditional Cash Transfer } \\
\text { Programme (PKH) }\end{array}$ & 6.285 people & - & - \\
\hline $\begin{array}{l}\text { Basic Food Program of Indonesia's } \\
\text { Ministry of Social Affairs }\end{array}$ & 9.495 people & - & - \\
\hline Cash Social Assistance (BST) & 10.473 people & - & - \\
\hline $\begin{array}{l}\text { Basic Food Program of the Ministry of } \\
\text { Social Affairs for the COVID- } 10\end{array}$ & 7.229 people & - & - \\
\hline $\begin{array}{l}\text { Central Java Provincial Government's } \\
\text { Social Safety Net }\end{array}$ & - & 101people & \\
\hline Basic Food for the COVID-19 & - & - & $\begin{array}{l}23.807 \\
\text { people }\end{array}$ \\
\hline Social Assistance for the Elderly & - & - & 500 people \\
\hline
\end{tabular}

Source: Kompas (2020)

In the efficiency, the Tegal Municipal Government and the Health Office conducted a rapid mass test in the community, especially in shopping centres. The Tegal City Government also suggested the public to do not travel to the COVID-19 red zone. These measures were taken to avoid future issues in case of continued easing of the PSBB (Media Indonesia, 2020). Hence, Tegal also implemented disinfectant spraying to end PSBB. In Tegal, the spraying of disinfectants is carried out by dozens of water cannons. It led Tegal City to reduce the spread of COVID-19 and became a green zone (iNewsJateng, 2020). However, when considering efficiency, it cannot be determined quickly. On a different point, handling COVID-19 should be looked at including the funds were to prepare for the policy transition from local lockdown to PSBB. Besides, the Municipal Government of Tegal has made as many as 150 employees from various agencies, including medical personnel, the National Police, the National Military, and Municipal Police.

In the effectivity, the Municipal Government of Tegal chose to maximize public communication and socialization in preventing the spread of the COVID-19 virus. Since Tegal City's stipulation as to the COVID-19 red zone, the Tegal City government and parliament have agreed to conduct preventative measures for COVID-19. The Municipal Government and parliament in Tegal have agreed to conduct massive prevention of COVID-19 (Jatengprov.go.id, 2020). Thus, the Tegal City Government believes that direct interaction with the people will significantly help Tegal City break the chain of the COVID-19 virus.

It can be noted that the effectiveness, openness, and accountability in coping with COVID19 are the keys to improve the people's economy in Tegal City. The effective handling is an optimal way to reduce the rate of spread of this pandemic immediately. In addition to that, the rules that have been implemented need to be obeyed by all societies. Therefore, protocols must be continuously reminded, such as social/physical distancing and maintaining personal hygiene. 


\section{Strategies of Malaysia's Kuala Lumpur City Hall (DBKL), Federal Territory of Kuala Lumpur, in Addressing Covid-19}

Participation. In the case of the Federal Territory of Kuala Lumpur, the DBKL has collaborated and participated with several governmental agencies in striving to control the spread of COVID-19 among the city's community. Several strategies have been implemented via this participation. On the first strategy is by participating with the Ministry of Housing and Local Government (KPKT) Malaysia via the Malaysian Fire and Rescue Department (JBPM) by the implementation of public sanitation processes in areas which frequently visited and touched by the public and homeless people, such as public landmarks, public market, public escalator and elevator, public street, public toilet, public amenities, and others. Furthermore, in striving to enforce the Standard Operation Procedure (SOP) by the authorities towards the public, the DBKL also participated with several other government authorities. Since the Conditional Movement Control Order (PKPB) has been implemented in the early of May 2020, the DBKL has initiated a collaboration with the Construction Industry Development Board (CIDB), Ministry of Health Malaysia (MOH), and Royal Malaysian Police (PDRM) which has conducted several inspections on the building construction site for the workers on the construction site is complies with the given SOP from the authorities.

Fairness. The Malaysian government always commit to give reasonable help and fairness to all people (Manan, 2020). The government also adduced that they will be offered jobs in the factory and general fields and living places too after MCO ended. In the meantime, they will undergo several trainings and courses so that they can enter the work field successfully. On the DBKL itself, they already prepared for almost 1,000 vacancies for the people who want to work in Kuala Lumpur. What they need to do is by coming to the Department of Labour Malaysia branch Kuala Lumpur (Sinar Harian, 2020). Based on the actions and efforts shown by DBKL to curb and solve the homeless issues in Kuala Lumpur particularly, it clearly shows that how serious they are in helping all the homeless people fairly to live in a good life, especially during this pandemic COVID-19. Meanwhile, no actions contributed by DBKL can be forgotten because they also have given a full contribution to make sure that all the homeless are safe.

Accountability. The DBKL is also accountable for ensuring that the spread of the COVID-19 pandemic in the community can be reduced from time to time. What DBKL should do is to ensure that all facilities under the supervision of its local authority comply with all requirements and guidelines issued by the authorities. Speaking of the role of local authorities, this is the responsibility of DBKL in ensuring that regular inspections continue to be carried out, the control of the road network entering public areas is well-controlled and ensure that there are no constraints between the public and local authorities in conducting their daily activities during this pandemic. Moreover, it also gives new starts for Kuala Lumpur residents, because other than curb the spreads of COVID-19, DBKL already took some actions in controlling and stopping the activities of illegal foreign hawkers who run their business around Kuala Lumpur.

Transparency. DBKL is always active in ensuring that in every action and implementation of a program and policy must consider the views of various parties concerned regardless of the 'bottom-up' or 'top-down' approach. This is to ensure that no party is marginalized in giving rational opinions and suggestions in implementing a program and policy. DBKL has taken the initiative by implementing 'Town-Hall Session' with some of the various stakeholders, business owners, related associations, and individuals to seat and discuss collectively on some issues that have been concerned lately, especially related to the business operation restriction within the MCO period. Any program and policy should be address to the public to ensure that the public is aware what that need to and not simply just let off their hand on some issues. DBKL needs to reassure the checks and balances principle between the public interest and the public safety during this pandemic crisis. For instance, DBKL has launched 'Town-Hall Session' on 27 September 2020 with some traders at Kasturi Walk and Art Lane at Pasar Seni.

Efficiency. The charter of efficient principles needs to be strengthened in every role of local authorities, acting as an efficient facilitator in every service provided by it. In this regard, DBKL always ensures that every task and instruction issued by it must be complied with by every business organization regulated under DBKL. Recognizing the recent spread of COVID-19, 
especially in Kuala Lumpur City region, DBKL acts proactively by giving mandatory instructions to every business vendor licensed under DBKL to ensure that every business guideline is based on the SOP provided by the government. DBKL has provided a great awareness to the public and then give the opportunity to the public to plan time well for before visiting any business area and public places. Indirectly, it provides efficient business to DBKL to carry out the public SOP monitoring process from time to time and gives space to the public to plan their travel time efficiently without not having trouble rearranging their period to go out and buy their daily needs.

Effectivity. The principle of effectiveness in dealing with the spread of the COVID-19 pandemic has also been practiced by DBKL. During the recent PKPB period, DBKL played an important role in ensuring the public's safety from being exposed to the spread of COVID-19. As a measure of efforts to minimize the movement of residents in public areas to buy goods, DBKL has launched a public market mobility program by using truck vehicles to be sold to the public in their respective residential areas at the time of PKPB. For example, the 'MyGrocer @ Wilayah' program has been launched by DBKL to make it easier for the public to buy necessities for sale in a residential area with a large population such as apartment houses. The results of several initiatives undertaken by the DBKL to control the number of COVID-19 transmission cases in the Kuala Lumpur City can be seen until 20 October 2020, showing that all areas in Kuala Lumpur still maintain within the yellow zone area and are under control by the authorities with assisted by the DBKL.

\section{Strategies of Thai's Chiang Mai Province, Provincial Administrative Organization (PAO)Municipality and Tambon Administrative Organization (TOA) in Coping with Covid-19}

Participation. In the case of Chiang Mai Province, PAO municipality and TAO were played the main role in early stages in the beginning of pandemic. PAO is the upper-tier that operates large-scale administrative duties and public services, while the municipally and TAO are the lower-tier responsible for small-scale duties (United Nations Development Programme, 2009). Moreover, according to Local Performance Assessment (LPA) Annual Report 2019 from Department of Local Administration reported that good governance in local administration in Thailand the average was outstanding at 90-100 percentage (Department of Local Administration, 2020). In this criterion, participation between local government and local people in Thailand were disappointed because all the solutions and decrees in coping the COVID-19 just came directly from the central government. Nevertheless, PAO in Chiang Mai, TAO, local community, and private sectors in Chiang Mai area were participated in many activities during the state of emergency decree. The villagers in Chang Puak Sub-district (TAO level) have cooperated to produce and distribute masks to other communities. These masks will be handed out to people who need them in the Chang Puak community. The group is currently producing 200 masks per day including normal cloth masks and a higher-grade mask which will be handed out to officials and personnel with higher risk of infection (CityNews, 2020a).

Fairness. Since Thai central government declared the emergency decree, it completed turned a local government unfairness to mitigate the pandemic for their local community. The limited power and budgeting to help and support the local community in pandemic time were late and lacking. Many local people suffered from this decree and lockdown policy. Obviously, both PAO municipality and TAO were insufficient budget to help their local people because the equal distribution to local people all controlled by the central government hand. Consequently, suffered people such as labour, elders, disability, and homeless have no opportunity to get a better condition since they became jobless during this pandemic. The only urgent solution while the whole country was locked down was 5,000-baht handouts over three months for 10 million households affected by the economic impact of COVID-19. In this case, it is obvious that the local government (PAO) in Chiang Mai, Tambon Administrative Organization (TAO) did not have any power and budget to support their people in early pandemic. On the other hand, the private sector played a crucial role in supporting and helping the local community and local government (CityNews, 2020b).

Accountability. Solely local government could not tackle the serious problem especially it concerned in life-and-dead during this pandemic. In the front line, ThailandVillage Health Page | 30 
Volunteer was played a crucial role. Local government in Chiang Mai Province, PAO municipalityand TAO, cooperated with Thailand Village Health Volunteer. They monitored and protected residents from the coronavirus. They are also credited as one of the reasons why COVID-19 figures in Thailand stayed relatively low. Since the lockdown policy implemented, many local governments in Thailand initiated to follow the central government policy in coping the COVID-19. Local governments started to close the road and set up an integrated check point to monitor and prevent outsiders into the community. This credited must honour to Thailand Village Health Volunteer. The Village Health Volunteer network was set up in 1977, after the Thai Ministry of Health partnered with the Japanese government to develop a primary health care system in all regions nationwide. The concept was also an embodiment of Thailand's pragmatism. Moreover, a big thank you to the Village Health Volunteer for provide health education, medicines, and make reports from WHO Thailand on Twitter as displayed in Figure 1.

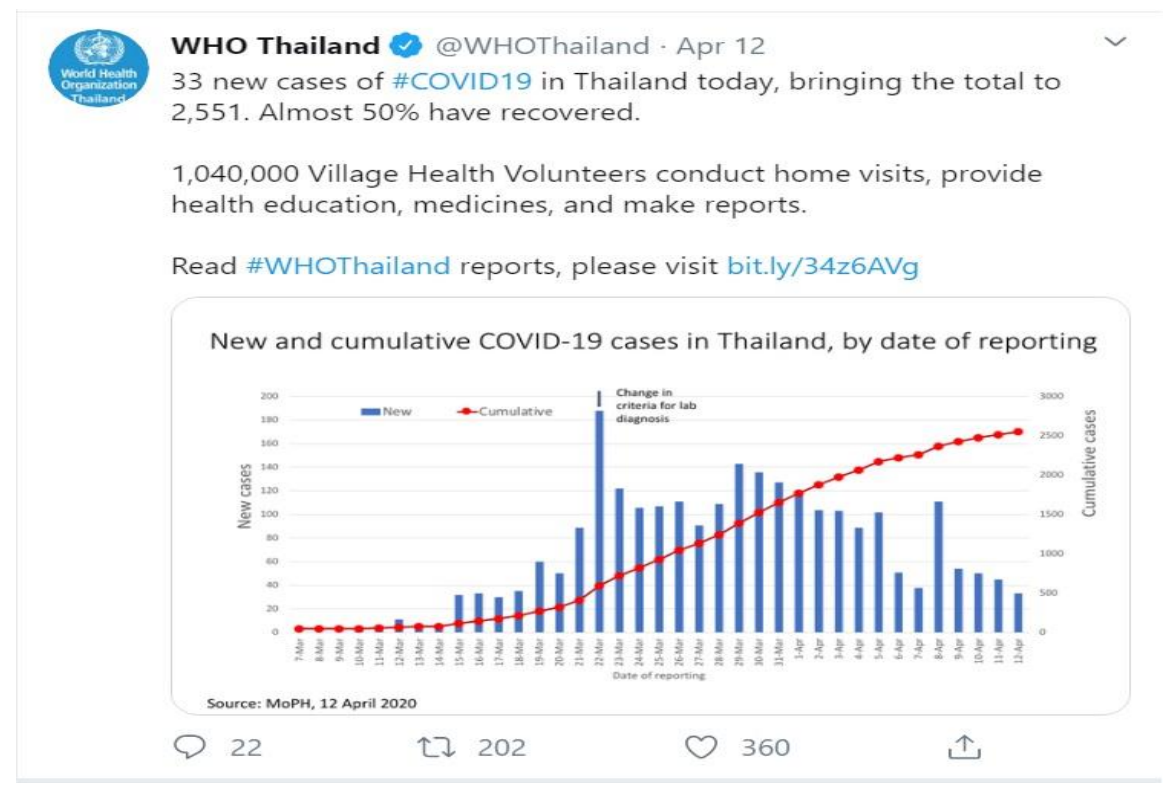

Figure. 1 WHO Thailand Congratulated them for Their Work Source: https://www.khaosodenglish.com/ (2020)

Transparency. In this criterion, PAO municipality and TAO in Chiang Mai was allowed from ministry of interior to spent annual fiscal in public hazard section no.11, no12, no13, no14, and no.15. Thus, to prevent and protect this pandemic, local government in Chiang Mai spent their annual fiscal in promoting the state of emergency decree. According to the national strategy on the prevention and suppression of corruption, The Nation of Prevention and Suppression Corruption Phase 3 (2017-2021) and Evaluation of Moral and Transparency in Operations of Government agencies (ITA) of the year 2019 have set government agencies to have measures in disseminating information to the public. Therefore, for transparency especially in pandemic local governments. They had to provide a basic information organization service for instance, Press release, Web Link, Rules and Regulations relevant to agency, Rules and Regulations relevant to private sector, Service information, and Communication Channels. In Chiang Mai, they set up public information centre to inform updated news and demonstrate their activities during this pandemic on their website such as www.chiangmaipao.go.th or www.oic.go.th/infocenter12/1249/ (Chiang Mai provincial Administrative Organization, 2020).

Efficiency. In Thailand, many government agencies cooperated in coping the COVID-19. The provincial and Tambon Administrative Organization (TAO) have more empirical efficiency since the domestic case occurred. According to City News (2020b), Charoen Sanguansat, Governor of Chiang Mai, along with various authorities, visited three checkpoints on the three major roads in Chiang Mai. The first checkpoint is at Baan Pa Kong on the Old Chiang Mai-Lamphun Road and the second is at BaabUmongNgam in Saraphee and the third is on the Superhighway. These checkpoints are still allowed for vehicles with strict screening; however, authorities say that they 
will close them entirely soon. Moreover, TOA and village health care were cooperated to block the local road. According to Kelly (2020) reported that a subdistrict of the northern Chiang Mai province is taking matters into its own hands by locking down residents and setting up checkpoints for people in the area. Volunteers at each checkpoint are checking the body temperature and handing out surgical masks, face shields, and hand wash gels to the people. Therefore, it was obvious that the efficiency in coping the COVID-19 in the Thailand case was leaded by the local government and its agencies by cooperating with local people. The data is shown Table 2.

Table 2. Comparative Strategies of Indonesia, Malaysia, and Thailand in Addressing the COVID-19

\begin{tabular}{|c|c|c|c|}
\hline Principles & Indonesia & Malaysia & Thailand \\
\hline Participation & $\begin{array}{l}\text { Well participation and } \\
\text { Collaboration between the local } \\
\text { government, the people, and } \\
\text { several agencies in handling the } \\
\text { COVID-19. }\end{array}$ & $\begin{array}{l}\text { Collaboration, involvement, and } \\
\text { cooperation between the public, local } \\
\text { government officials, and multiple } \\
\text { agencies provided in coping the } \\
\text { COVID-19. }\end{array}$ & $\begin{array}{l}\text { Participation between the } \\
\text { government and the people is } \\
\text { quite disappointed because the } \\
\text { government is more dominant. }\end{array}$ \\
\hline Fairness & $\begin{array}{l}\text { Lack of fairness in distributing } \\
\text { the COVID-19 assistance. Some } \\
\text { people did not received } \\
\text { assistance yet. }\end{array}$ & $\begin{array}{l}\text { Fairness in distributing help to the } \\
\text { people particularly for the homeless. }\end{array}$ & $\begin{array}{l}\text { Lack of fairness in helping the } \\
\text { people during lockdown due to } \\
\text { the limited power and } \\
\text { budgeting of the local } \\
\text { government. }\end{array}$ \\
\hline Accountability & $\begin{array}{l}\text { Accountability is well } \\
\text { implemented, and the } \\
\text { government has responded } \\
\text { quickly to this pandemic by } \\
\text { utilizing their facilities, creating } \\
\text { strict regulation, and employing } \\
\text { the central government policy. }\end{array}$ & $\begin{array}{l}\text { The government is accountable for } \\
\text { ensuring that routine checks continue } \\
\text { to be carried out, the regulation of the } \\
\text { road network accessing public areas } \\
\text { is well-controlled, and these } \\
\text { restrictions do not prevent people } \\
\text { from carrying out everyday activities } \\
\text { during this pandemic. }\end{array}$ & $\begin{array}{l}\text { Accountability is well enforced, } \\
\text { and the local government in } \\
\text { collaboration with Thailand } \\
\text { Village Health Volunteer has } \\
\text { monitored and protected } \\
\text { residents from the coronavirus. }\end{array}$ \\
\hline Transparency & $\begin{array}{l}\text { Transparency is enforced quite } \\
\text { well, however, several expenses } \\
\text { including the COVID-19 } \\
\text { assistance must be reported to } \\
\text { avoid discrepancies in data. }\end{array}$ & $\begin{array}{l}\text { The government ensure the } \\
\text { transparency to be enforced by } \\
\text { providing Town-Hall Session' with } \\
\text { different stakeholders, business } \\
\text { owners, related associations, and } \\
\text { individuals discuss collectively on } \\
\text { some issues that have been concerned } \\
\text { lately, including the COVID-19. }\end{array}$ & $\begin{array}{l}\text { The transparency in local } \\
\text { governments in was forced } \\
\text { based on the national strategy } \\
\text { on the prevention and } \\
\text { suppression of corruption } \\
\text { during this pandemic. To } \\
\text { realize that, the government set } \\
\text { up center of public information. }\end{array}$ \\
\hline Efficiency & $\begin{array}{l}\text { Even the government has } \\
\text { utilized its resources optimally } \\
\text { to ensure efficiency; however, } \\
\text { this principle cannot be } \\
\text { determined quickly due to } \\
\text { several things that need to be } \\
\text { considered like funding. }\end{array}$ & $\begin{array}{l}\text { To ensure efficiency, the government } \\
\text { has issued instruction for public } \\
\text { safety regulation. it provides efficient } \\
\text { business to DBKL to carry out the } \\
\text { public SOP monitoring process from } \\
\text { time to time and gives space to the } \\
\text { public to plan their travel time } \\
\text { efficiently. }\end{array}$ & $\begin{array}{l}\text { Ensuring efficiency by } \\
\text { cooperating several } \\
\text { stakeholders including local } \\
\text { people to become volunteers in } \\
\text { coping the COVID-19. }\end{array}$ \\
\hline Effectivity & $\begin{array}{l}\text { The principle of effectiveness has } \\
\text { been enforced by conducting } \\
\text { massive socialization of the } \\
\text { COVID-19 as a preventive } \\
\text { measure. }\end{array}$ & $\begin{array}{l}\text { The government has launched a } \\
\text { public market mobility program using } \\
\text { truck vehicles to be sold to the public } \\
\text { in their respective residential areas. } \\
\text { This aims to protect the people from } \\
\text { the spread of the COVID-19 } \\
\text { effectively. }\end{array}$ & $\begin{array}{l}\text { The government and village } \\
\text { health volunteer succeed of } \\
\text { stopping the COVID-19 } \\
\text { pandemic in domestic by } \\
\text { applying a provocation search } \\
\text { in their area. }\end{array}$ \\
\hline
\end{tabular}

Source: Compiled by the Authors.

Effectivity. The most effectivity and success of stopping the COVID-19 pandemic in domestic, which was the provocation of TOA and village health volunteer in their area. Village health volunteers' proactive surveillance and control operations have been tangible since late February. After that spread took place in early March, COVID-19 patients in provinces have finally outnumbered in Bangkok. On 29 March 2020, the fan page of Village Health Volunteer 4.0 released the guidance on village health volunteers' door-to-door campaign for their missions to combat COVID-19. The Health Service Support Department has given village health volunteers four missions. The first is to visit every household in their jurisdictions to educate them on the disease and the protective measures of "eating hot food, using serving spoons, washing hands, wearing masks, and doing exercise". The second is to conduct health screenings for people 
including those with risks. The third is to refer those with risks to local public-health officials. The fourth is to follow up and report results (The Human Resources for Health Research and Development Office, 2020).

Hence, to prevent the spread of the Corona outbreak, the local government and Village Health Volunteer must coordinate and divided their operation into 2 parts. On the one hand, local government provided Nebulizer equipment Disinfectant solution and spray with a portable disinfectant to clean up their area. Also, they taught local community to make a fabric mask, alcohol gel, and information of a new normal daily life such as social distancing, hand washing, and observe COVID-19 symptom. On the other hand, Village Health Volunteerfocus on educating and advising people on COVID-19 prevention, symptoms, and self-observationv (Kertesz, Brown, Bunluesin, 2020).

\section{CONCLUSION}

Discussion and findings indicate that the three countries have formed their own ways of dealing with the COVID-19. Therefore, Good Governance (GG) concepts contribute to these states having advantages. An analysis of the Tegal City in Indonesia showed that the realization of transparency is successful. It can be proven by the Tegal government's responsiveness in reacting to the first case of the COVID-19 virus in the Tegal City. Tegal has also introduced stringent regulations to avoid the spread of the COVID-19, and so forth. In Malaysia, the main factor contributing to the performance of the DBLK Government was its active involvement in participation. The participation and cooperation between the government and various stakeholders have created a successful policy as the primary strategy for the DBLK Government to fight against this pandemic. In the meantime, Chiang Mai City has a special benefit of being able to be kept accountable due to the accountability concept. The government reacts rapidly in the face of this Coronavirus outbreak by cooperating with Thailand Village Health Volunteer. From this point forward, the Chiang Mai Government started collaborating with the local people as volunteers to deal with the COVID-19.

Table 2 summarize comparative strategies of local governments in Indonesia, Malaysia, and Thailand in addressing the COVID-19 situation. If Indonesia's Tegal City is more successful in applying the transparency principle, Malaysia's DBKL Government is more excellent in realizing the participation principle. Meanwhile, Thai's Chiang Mai City has a well performance in operating the accountable principle. It demonstrates that each country has a different strategy which is suitable in dealing with this pandemic situation.

\section{REFERENCES}

Afonso, W. (2021). Planning for the unknown: Local government strategies from the fiscal year 2021 budget season in response to the COVID-19 pandemic. State and Local Government Review, XX(X), 1-13. https://doi.org/10.1177/0160323X211032728

Aljazeera. (2020, April 12). US overtakes Italy with highest coronavirus deaths: Live updates. Aljazeera. https://www.aljazeera.com/news/2020/04/overtake-italy-coronavirusdeaths-live-updates-200410232614536.html

Angel, J. L., \& Mudrazija, S. (2020). Local government efforts to mitigate the Novel Coronavirus pandemic among older adults. Journal of Aging \& Social Policy, 32(4-5), 439-449. https://doi.org/10.1080/08959420.2020.1771240

BBC. (2020, March 7). Coronavirus: Italy reports biggest daily jump in death toll. BBC News. https://www.bbc.com/news/world-europe-51777049

Bloomberg. (2020, March 21). Thailand Imposes Partial Lockdown of Capital as Virus Cases Soar. Bloomberg. https://www.bloomberg.com/news/articles/2020-03-21/thailand-confirms89-more-coronavirus-cases-taking-total-to-411

Chiang Mai provincial Administrative Organization. (2020). public dissemination of information on the website. Chiang Mai Provincial Administrative Organization. https://www.chiangmaipao.go.th/th/news_detail.php?ID=7509

CityNews. (2020a, March 26). heckpoints on major roads into Chiang Mai. CityNews. https://www.chiangmaicitylife.com/citynews/covid-19 
CityNews. (2020b, March 27). Community comes together to sew masks. Https://Www.Chiangmaicitylife.Com/.

https://www.chiangmaicitylife.com/citynews/covid-19/community-comes-together-tosew-masks/

CNBC. (2020, April 23). Terungkap! Alasan Jokowi Pilih PSBB Bukan Lockdown. CNBC. https://www.cnbcindonesia.com/news/20200423075855-4-153804/terungkap-alasanjokowi-pilih-psbb-bukan-lockdown

Creswell, J. W. (2013). Qualitative inquiry and research design: Choosing among five approaches (Third Edit). Sage Publications.

Denzin, N. K., \& Lincoln, Y. S. (2011). Introduction: The discipline and practice of qualitative research (In Denzin,). Sage.

Department of Local Administration. (2020). Local Performance Assessement (LPA) Annual Report 2019. Department of Local Administration. http://www.dla.go.th/index.jsp

Detik. (2020). Tegal Local Lockdown, Walkot: Yang Mau Masuk Kota Harus Steril!tle. DetikNews. https://news.detik.com/berita-jawa-tengah/d-4955842/tegal-local-lockdown-walkotyang-mau-masuk-kota-harus-steril

Flyvbjerg, B. (2011). Thesage handbook of qualitative research (Case study). Sage.

Gatra. (2020). Bantuan Warga Terdampak Covid-19 di Kota Tegal Tak Merata. https://www.gatra.com/detail/news/477408/kebencanaan/bantuan-warga-terdampakcovid-19-di-kota-tegal-tak-merata

Green, D., \& Loualiche, E. (2020). State and local government employment in the COVID-19 crisis. Journal of Public Economics, 193, 1-10. https://doi.org/https://doi.org/10.1016/j.jpubeco.2020.104321

IMF. (1997). Good Governance: The IMF's Role. Washington DC.

IMF. (2014). Factsheet: The IMF and Good Governance. Washington DC.

iNewsJateng.id. (2020). Pemkot Tegal Semprot Massal Disinfektan Akhiri PSBB, Warga Diminta Tak Keluar Rumah. INews. https://jateng.inews.id/berita/pemkot-tegal-semprot-massaldisinfektan-akhiri-psbb-warga-diminta-tak-keluar-rumah

Jatengprov.go.id. (2020). Pemerintah dan Dewan Sepakat Percepat Penanganan Corona di Kota Tegal. Portal Berita Pemerintah Provinsi Jawa Tengah. https://jatengprov.go.id/beritadaerah/pemerintah-dan-dewan-sepakat-percepatpenanganan-corona-di-kota-tegal/

Kertesz, D., Brown, R., \& Bunluesin, S. (2020). Thailand's 1 million village health volunteers "unsung heroes" - are helping guard communities nationwide from COVID-19. Worl Health Organization. https://www.who.int/thailand/news/feature-stories/detail/thailands-1million-village-health-volunteers-unsung-heroes-are-helping-guard-communitiesnationwide-from-covid-19

Kompas. (2020). Nama Penerima Bansos Corona di Tegal Akan Dipajang di Kelurahan. Kompas.Com. $\quad$ https://regional.kompas.com/read/2020/05/15/10271301/namapenerima-bansos-corona-di-tegal-akan-dipajang-di-kelurahan

Kompas TV. (2020). Banyak Pemudik Jadi Alasan Kota Tegal Berlakukan PSBB. https://www.youtube.com/watch?v=QxTatDrzSZU

Manan, N. F. A. (2020). Isu gelandangan perlu ada pengakhiran: Annuar Musa. https://www.sinarharian.com.my/article/77653/BERITA/Nasional/Isu-gelandanganperlu-ada-pengakhiran-Annuar-Musa.

Media Indonesia. (2020). Pemkot Tegal akan Gelar Rapid Test Acak di Pusat Berbelanjaan. Media Indonesia. https://mediaindonesia.com/read/detail/313627-pemkot-tegal-akan-gelarrapid-test-acak-di-pusat-berbelanjaan

Merdeka. (2020, April). Perangi Virus Corona, Pemda Realokasi Anggaran Hingga Rp85 Triliun. Merdeka.Com. https://www.merdeka.com/uang/perangi-virus-corona-pemda-realokasianggaran-hingga-rp-85-triliun.html

Nemec, J., \& Špaček, D. (2020). The Covid-19 pandemic and local government finance: Czechia and Slovakia. Journal of Public Budgeting, Accounting \& Financial Management, 32(5), 837-846. https://doi.org/10.1108/JPBAFM-07-2020-0109

Page | 34 
NewsDetik. (2020). Tangkal Corona di Kota Tegaldari Lockdown hingga PSBB.

Republika. (2020, April). Usainya PSBB dan Kebanggaan Wong Tegal. Republika.Co.Id. https://republika.co.id/berita/qavp8i393/usainya-psbb-dan-kebanggaan-wong-tegal

Satispi, E., Tuti, R. W. D., Fathani, A. T., \& Kaewhanam, P. (2021). Local government respond to COVID-19 pandemics: A study of South Tangerang City. Journal of Governance and Public Policy, 8(2), 82-92. https://doi.org/https://doi.org/10.18196/jgpp.v8i2.11439

Sinar Harian. (2020). Masih ada sinar harapan untuk gelandangan bandar. https://www.sinarharian.com.my/article/87998/BERITA/Nasional/Masih-ada-sinarharapan-untuk-gelandangan-bandar

The Human Resources for Health Research and Development Office. (2020). Village Health Volunteers are Hard-to-Imitate Worker Ants in Thailand's Healthcare System. The Human Resources for Health Research and Development Office (HRDO). https://hrdo.org

Tim Indonesia Governance Index. (2014). Menata Indonesia dari Daerah: LaporanEksekutif Indonesia Governance Index 2014. Kemitraan.

United Nations Development Programme. (1997). Governance for Sustainable Human Development: A UNDP Policy Document. www.pogar.org/publications/other/undp/governance/undppolicydoc97-e.pdf

United Nations Development Programme. (2009). Capacity Building and Civic Education on Support of Decentralisation and Local Governance in Thailand. United Nations Development Programme.

Wong, C.-H. (2020). Malaysia: coronavirus, political coup and lockdown. The Round Table, 1-2.

World Bank. (1992). Governance and Development.

World Bank. (1994). Governance: The World Bank Experience.

World Health Organization. (2020). WHO Timeline - COVID-19. World Health Organization (WHO). https://www.who.int/news-room/detail/27-04-2020-who-timeline---covid-19 